\title{
Analisis Pengaruh Rasio Keuangan terhadap Return Saham PT. Adhi Karya (Persero) Tbk.
}

\author{
Muhammad Fuad \\ Fakultas Ekonomi Universitas Samudra \\ e-mail: muhammadfuad@unsam.ac.id \\ Novia Al Mughni \\ Fakultas Ekonomi Universitas Samudra \\ e-mail: novia_almughni@gmail.com
}

\begin{abstract}
Abstrak
Penelitian ini menganalisis pengaruh dari rasio-rasio keuangan yang meliputi likuiditas, solvabilitas dan profitabilitas, terhadap return saham PT. Adhi Karya (Persero) Tbk. Rasio likuiditas, solvabilitas dan profitabilitas, masing-masing direpresentasi oleh current ratio, debt to equity ratio dan return on investment. Data sekunder berupa laporan keuangan selama periode 2008-2016, dan di analisis menggunakan metode regresi linier berganda. Hasil-hasil yang diperoleh menyatakan bahwa ketiga rasio keuangan memiliki pengaruh positif dan signifikan terhadap return saham dari PT. Adhi Karya (Persero) Tbk. Dengan demikian, baik hipotesis pertama maupun kedua dapat diterima kebenarannya. Pengaruh terbesar dimiliki oleh rasio profitabilitas. Koefisien determinasi menunjukkan ketiga rasio keuangan yang dianalisis memiliki kemampuan relatif rendah dalam menjelaskan perubahan dari return saham obyek penelitian.
\end{abstract}

Kata kunci: Likuiditas, solvabilitas, profitabilitas, return saham.

\section{PENDAHULUAN}

Return saham merupakan tingkat imbal hasil dari kepemilikan saham oleh investor di pasar modal (Gumanti, 2017; Damodaran, 2014). Tentu saja para investor selalu mengharapkan adanya rate of return yang selalu positif dan terus menaik dari waktu ke waktu, karena kondisi itu menunjukkan semakin meningkatkan kekayaan investasi mereka. Sebaliknya, return yang negatif mengindikasikan adanya kerugian yang diderita oleh investor atas investasi saham yang dilakukan. Return saham bisa pula dihubungkan sebagai indikator keberhasilan atau kegagalan dari strategi investasi yang dilakukan investor.

Di sisi lain, rate of return juga berperan penting bagi perusahaan penerbit saham atau emiten dalam upayanya untuk bertumbuh secara berkelanjutan (Halim, 2015; Fitriana et al., 2016; Leksono et al., 2015). Tingkat return yang positif dan menaik dari waktu ke waktu mengindikasikan nilai perusahaan pada pandangan investor mengalami peningkatan. Return saham yang menaik bisa juga menunjukkan bahwa kinerja atau prestasi yang dihasilkan perusahaan memperoleh sentimen positif dari pasar.

PT. Adhi Karya (Persero) Tbk. merupakan salah satu perusahaan yang didirikan oleh pemerintah dan saat ini telah menjadi perusahaan publik yang bergerak di bidang konstruksi. Seperti telah dinyatakan, sebagai perusahaan yang telah terdaftar di pasar modal, maka pergerakan return saham menjadi penting peranannya di dalam pengembangan maupun penciptaan daya saing bisnisnya di masa datang.

Salah satu bahan analisis yang digunakan investor untuk mengestimasi tingkat return masa depan suatu saham adalah laporan keuangan emiten saham bersangkutan 
(Gumanti, 2017; Tandelilin, 2010; Rusadi \& Hermanto, 2017). Laporan keuangan itu selanjutnya dianalisis antara lain melalui metode rasio keuangan. Rasio keuangan yang umum digunakan adalah rasio-rasio likuiditas, solvabilitas, dan profitabilitas. Hasil analisis menggunakan rasio keuangan itu akan menunjukkan bagaimana kinerja perusahaan bersangkutan dan akan memiliki peran penting dalam pertimbangan investasi yang dijalankan oleh investor (Copeland et al., 2013; Taufik et al., 2016; Fuad et al., 2017). Dalam penelitian ini, rasio keuangan digunakan para investor untuk mengukur kinerja PT. Adhi Karya (Persero) Tbk., dan hasil penilaian akan mempengaruhi keputusan investasi dari para investor atas perusahaan.

Penelitian ini bertujuan menganalisis bagaimana pengaruh baik secara parsial ataupun simultan dari rasio keuangan yang terdiri dari rasio-rasio likuiditas, sovabilitas dan profitabilitas, terhadap return saham. Obyek penelitian yang dianalisis adalah PT. Adhi Karya (Persero) Tbk. Hasil analisis ini berkontribusi memberi bahan pertimbangan tambahan bagi para investor dalam membuat keputusan investasi, khususnya untuk saham PT. Adhi Karya (Persero) Tbk maupun saham-saham lainnya secara umum. Hasil analisis juga memberikan referensi bagi para emiten yang beraktivitas di BEI mengenai hubungan antara laporan keuangan yang mereka hasilkan dengan pergerakan return saham mereka.

\section{Return Saham}

Return adalah tingkat keuntungan yang dinikmati oleh pemilik atau pemegang saham atas investasi saham yang dilakukannya (Gumanti, 2017). Return juga merupakan salah satu faktor yang memotivasi investor untuk berinvestasi dalam saham serta merupakan imbalan atas keberaniannya menanggung risiko dari investasi yang dilakukannya (Tandelilin, 2010).

Return atas saham terdiri dari dua unsur, yaitu capital gain dan yield (Halim, 2015). Capital gain merupakan keuntungan yang diperoleh investor saat harga jual saat ini dari saham yang dimilikinya lebih tinggi dari harga belinya. Sebaliknya, jika harga jual saham saat ini lebih rendah daripada harga belinya, maka investor mengalami kerugian atau capital loss (Gumanti, 2017; Damodaran, 2014). Yield adalah aliran kas yang diterima investor secara periodik, seperti dividen. Dividen adalah bagian keuntungan yang diperoleh investor pada akhir tahun karena kepemilikan saham, biasanya satu kali dalam setahun setelah nilai dividen diputuskan dalam rapat umum pemegang saham (RUPS) (Harjito \& Martono, 2011; Sartono, 2014).

Return saham dinyatakan dalam nilai persentase (Fitriana et al., 2016' Rusadi \& Hermanto, 2017). Return saham dihitung berdasarkan perbandingan antara harga saham periode saat ini dengan harga saham periode sebelumnya.

\section{Rasio Keuangan}

Rasio keuangan adalah perbandingan antara dua atau lebih pos laporan keuangan yang mempunyai hubungan yang relevan (Harahap, 2015). Rasio keuangan dapat digunakan untuk menilai prestasi keuangan yang dicapai perusahaan ataupun untuk mengevaluasi apakah terdapat penyimpanganpenyimpangan dalam pelaksanaan aktivitas operasional perusahaan dalam aspek keuangan (Kasmir, 2014; Subramanyam \& Wild, 2013). Teknik perhitungan rasio dinilai memberikan hasil perbandingan yang lebih bermanfaat daripada melihat angka saja (Halim, 2015).

Tiga tipe rasio keuangan yang umum digunakan adalah rasio likuiditas, rasio solvabilitas, dan rasio profitabilitas. Rasio likuiditas merupakan rasio yang menilai kemampuan perusahaan untuk memenuhi bentuk-bentuk kewajiban jangka pendeknya sebelum jatuh tempo; rasio solvabilitas adalah rasio yang memperlihatkan kemampuan perusahan untuk memenuhi bentuk-bentuk kewajiban jangka pendek maupun jangka panjangnya saat mengalami kebangkrutan; dan, rasio profitabilitas merupakan rasio yang menunjukkan kemampuan perusahaan dalam mengelola aset-aset yang dimilikinya untuk menghasilkan laba (Kasmir, 2014; Taufik et al., 2016). 
Rasio likuiditas yang digunakan dalam penelitian ini adalah current ratio (CR), yaitu perbandingan antara aktiva lancar dan kewajiban lancar (Murhadi, 2013; Harahap. 2015). Rasio ini mengindikasikan seberapa banyak total aktiva lancar (yaitu: kas, bank, sekuritas, piutang, dan persediaan) yang tersedia di dalam perusahaan untuk menutupi semua beban kewajiban jangka pendeknya yang segera jatuh tempo (Brigham \& Houston, 2011; Kasmir, 2014). Semakin besar nilai dari CR maka kinerja perusahaan dinyatakan semakin baik.

Rasio solvabilitas yang digunakan dalam penelitian ini adalah debt to equity ratio (DER), yaitu perbandingan antara total beban kewajiban yang ada, baik kewajiban jangka pendek maupun jangka panjang, atas total ekuitas yang dimiliki perusahaan (Halim, 2015; Harahap, 2015). Rasio DER mengindikasikan proporsi relatif dari ekuitas dan utang yang digunakan untuk membiayai aktiva perusahaan (Fahmi, 2014; Taufik et al., 2016). Semakin besar nilai DER maka kinerja perusahaan dinyatakan semakin kurang baik.

Rasio proftabilitas yang digunakan dalam penelitian ini adalah return on investment (ROI), yaitu perbandingan antara laba bersih yang diperoleh perusahaan dan total aktiva yang dikelola perusahaan (Copeland et al., 2013; Kasmir, 2014). Rasio ini bermanfaat untuk menunjukkan tingkat efektivitas manajemen dalam mengelola bentuk-bentuk aktiva yang diinvestasikannya (Fitriana et al., 2016; Brigham \& Houston, 2011). Semakin besar nilai ROI maka kinerja perusahaan dinyatakan semakin baik.

\section{Hipotesis dan Kerangka Penelitian}

Penelitian ini menganalisis pengaruh rasio keuangan terhadap return saham, dengan obyek penelitian pada PT. Adhi Karya (Persero), Tbk. Rasio keuangan yang digunakan meliputi rasio likuiditas, rasio solvabilitas, dan rasio profitabilitas.

Rasio likuiditas dalam penelitian ini menyatakan kemampuan perusahaan dalam memenuhi semua kewajiban lancar atau jangka pendek menggunakan aktiva lancarnya pada saat jatuh tempo (Murhadi, 2013;
Harahap. 2015). Semakin besar nilai rasio likuiditas, maka perusahaan dinilai berkinerja semakin baik. Hal ini karena menunjukkan semakin mampunya perusahaan menutupi kewajiban lancarnya menggunakan aktiva lancar yang dimiliki sehingga meminimalkan risiko gagal bayar, dan berarti meminimalkan risiko yang ditanggung pemegang saham. Hal ini memberikan sinyal positif dan menarik lebih banyak investor untuk berinvestasi sehingga meningkatkan nilai perusahaan (Brigham \& Houston, 2011). Hasil studi Rusadi dan Hermanto (2017), Lestari et al. (2016), Safitri \& Yulianto (2015), Pratiwi dan Putra (2015), Wingsih (2013), serta Farkhan dan Ika (2012), menemukan rasio likuiditas berpengaruh positif terhadap return saham. Namun demikian, hasil studi milik Fitriana et al. (2009) serta Thrisye dan Simu (2013) menemukan bahwa rasio likuiditas tidak berpengaruh terhadap return saham. Dengan demikian, dihipotesiskan bahwa:

\section{$H_{1}$ : Rasio likuiditas berpengaruh positif terhadap return saham}

Rasio solvabilitas dalam penelitian ini menyatakan besaran perbandingan antara total kewajiban dan total ekuitas yang dikelola perusahaan (Halim, 2015; Harahap, 2015). Semakin besar nilai rasio solvabilitas, maka perusahaan dinilai berkinerja kurang baik. Hal ini karena utang yang dikelola lebih besar dari ekuitas yang dimiliki perusahaan demi menutupi beban itu saat perusahaan menghadapi krisis keuangan, sehingga memperbesar risiko kebangkrutan yang dihadapi perusahaan. Risiko itu akan memberikan sinyal negatif bagi para investor untuk kemudian cenderung tidak memilih saham perusahaan yang bersangkutan, dan berakibat menurunnya nilai perusahaan (Brigham \& Houston, 2011). Hasil studi Rusadi dan Hermanto (2017), Taufik et al. (2016), Fitriana et al. (2016), Safitri dan Yulianto (2015), Thrisye dan Simu (2013), Asnita \& Astohar (2012), Ngaisah (2008) serta Papanastasopulos et al. (2010), mengidentifikasi rasio solvabilitas memiliki pengaruh negatif atas return saham. Tetapi hasil penelitian Wingsih (2013), Leksono et al. (2013), Nuryanah (2013), Farhan dan Ika (2012) serta Susilowati dan Turyanto (2011) 
menemukan rasio solvabilitas berpengaruh positif terhadap return saham. Dengan demikian, dinyatakan hipotesis bahwa:

\section{$\mathrm{H}_{2}$ : Rasio solvabilitas berpengaruh negatif terhadap return saham}

Rasio profitabilitas dalam penelitian ini menunjukkan kemampuan perusahaan dalam menghasilkan laba melalui pengelolaan asetaset yang diinvestasikan (Copeland et al., 2013; Kasmir, 2014). Nilai rasio profitabilitas yang semakin besar menunjukkan perusahaan semakin mampu mengelola total aktivanya dalam menghasilkan laba. Para investor menyukai perusahaan yang memiliki rasio profitabilitas yang tinggi karena kondisi itu memberikan sinyal positif terkait kinerja perusahaan, dan selanjutnya mempertinggi nilai perusahaan (Halim, 2015). Hasil studi Rusadi dan Hermanto (2017), Leksono et al. (2016), Nuryana (2013), Thrisye dan Simu (2013), Farkhan dan Ika (2012), Fitriana et al. (2009), serta Susilowati dan Turyanto (2011), mengidentifikasi bahwa rasio profitabilitas berpengaruh positif terhadap return saham. Namun demikian, hasil studi milik Lestari et al. (2016), Safitri dan Yulianto (2015), Arista dan Astohar (2012), serta Wingsih (2013), menemukan bahwa rasio profitabilitas berpengaruh negatif terhadap return saham. Dengan demikian, dinyatakan hipotesis:

$\mathrm{H}_{3}$ : Rasio profitabilitas berpengaruh positif terhadap return saham

Berdasarkan hasil telaah literatur serta hipotesis yang dikemukakan, maka kerangka penelitian ini adalah seperti tampak dalam Gambar 1.

\section{METODE PENELITIAN}

\section{Sumber dan Metode Pengumpulan Data}

Obyek penelitian adalah PT. Adhi Karya (Persero) Tbk. Sumber data adalah data sekunder, berupa laporan keuangan yang terdiri dari neraca dan laporan laba-rugi serta harga saham milik perusahaan.

Data dikumpulkan melalui metode dokumentasi, dengan periode selama 2008 sampai 2016. Data diperoleh dari website Bursa Efek Indonesia, yaitu www.idx.co.id.

\section{Metode Analisis Data}

Data penelitian dianalisis menggunakan metode regresi linier berganda, dengan mencakup tiga variabel independen dan satu variabel dependen. Variabel independen terdiri dari rasio likuiditas (X1), rasio solvabilitas (X2), dan rasio profitabilitas (X3). Variabel dependen adalah return saham perusahaan yang direpresentasi oleh harga saham pada akhir tahun (Y). Hipotesis diuji melalui uji $\mathrm{t}$ ( $t$-test) dan uji $\mathrm{F}$ ( $F$-test), dengan kriteria pengujian menggunakan level of significance $(\alpha)$ sebesar 0,05 atau $5 \%$.

Indikator dari rasio likuiditas dalam penelitian ini adalah Current Ratio (CR), dengan menggunakan skala rasio atau dalam satuan persentase (\%). Rumus dari CR adalah (Halim, 2015):

$$
C R=\frac{\text { Current Assets }}{\text { Current Liabilities }} \times 100 \%
$$

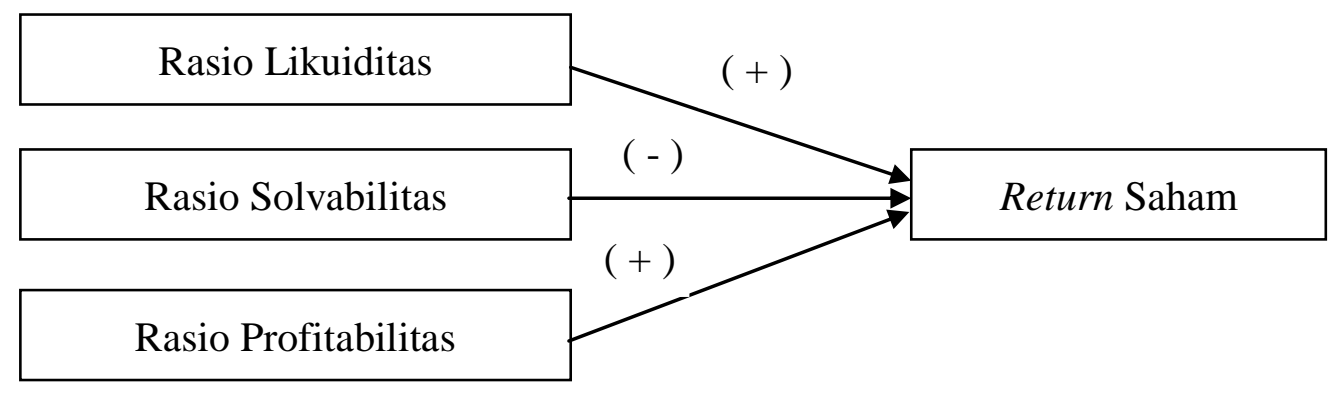

Sumber: Diolah peneliti, tahun 2017.

\section{Gambar 1. Kerangka Penelitian}


dimana current assets meliputi semua aktiva lancar yang dimiliki perusahaan, sementara current liabilities adalah semua kewajiban lancar atau jangka pendek yang ditanggung perusahaan dalam satu periode laporan keuangan.

Indikator dari rasio solvabilitas adalah Debt to Equity Ratio (DER), dengan menggunakan skala rasio atau dalam satuan persentase (\%). Rumus dari DER adalah (Halim, 2015):

$$
D E R=\frac{\text { Total Debt }}{\text { Equity }} \times 100 \%
$$

dimana total debt meliputi semua beban utang atau kewajiban yang ditanggung perusahaan, baik bersifat jangka pendek maupun jangka panjang; sementara equity adalah total modal sendiri atau ekuitas yang dimiliki perusahaan dalam satu periode laporan keuangan.

Indikator dari rasio profitabilitas adalah Return on Investment (ROI), dengan menggunakan skala rasio atau dalam satuan persentase (\%). Rumus dari ROI adalah (Halim, 2015):

$$
R O I=\frac{\text { Earning before Interest and Tax }}{\text { Total Asset }} \times 100 \%
$$

dimana earning before interest and tax adalah nilai laba operasional atau laba yang diperoleh perusahaan sebelum dikurangi beban bunga dan pajak; sementara total asset meliputi semua aktiva atau asset yang dimiliki perusahaan, baik bersifat jangka pendek serta jangka panjang.

Indikator dari return saham adalah harga saham akhir tahun (closing price) dengan menggunakan skala rasio atau dalam satuan persentase (\%). Rumus menghitung return saham adalah (Gumanti, 2017):

$$
\text { Return }=\frac{P_{t}-P_{t-1}}{P_{t-1}} \times 100 \%
$$

dimana $P_{t}$ adalah harga (nilai) saham pada periode $t$; sementara $P_{t-1}$ adalah harga (nilai) saham pada periode sebelumnya atau $t-1$.

\section{HASIL ANALISIS \\ Analisis Deskriptif}

Trend fluktuasi dari harga saham dan return saham PT. Adhi Karya (Persero) Tbk. dirangkum dalam Tabel 1. Tabel tersebut menunjukkan bahwa harga saham obyek penelitian cenderung terus mengalami peningkatan sejak tahun 2008 sampai 2016, dimana terjadi kenaikan sebesar Rp. 1.851 per lembar atau 808,29\% dari tahun 2008 sebesar Rp. 229 per lembar menjadi Rp. 2.080 per lembar di tahun 2016. Berdasarkan return, Tabel 1 juga menunjukkan bahwa saham PT. Adhi Karya (Persero) Tbk. mayoritas mengalami gain; walau juga sempat mengalami loss pada tahun 2011, 2013, 2015 dan 2016 yaitu masing-masing sebesar $36,26 \%, 14,19 \%, 27,53 \%$, dan $2,80 \%$.

Tabel 1. Trend Harga dan Return Saham PT. Adhi Karya (Persero) Tbk. Tahun 2008-2016

\begin{tabular}{ccc}
\hline Tahun & Harga Saham (Rp./lembar) & Return Saham (\%) \\
\hline 2008 & 229 & - \\
2009 & 348 & 51,96 \\
2010 & 772 & 54,92 \\
2011 & 492 & $(36,26)$ \\
2012 & 1.493 & 203,45 \\
2013 & 1.281 & $(14,19)$ \\
2014 & 2.953 & 130,52 \\
2015 & 2.140 & $(27,53)$ \\
2016 & 2.080 & $(2,80)$ \\
\hline
\end{tabular}

Sumber: www.idx.co.id (diolah), Tahun 2017. 


\section{Tabel 2. Trend Current Ratio, Debt to Equity Ratio dan Return on Investment PT. Adhi Karya (Persero) Tbk. Tahun 2008-2016}

\begin{tabular}{cccc}
\hline Tahun & $\begin{array}{c}\text { Current Ratio } \\
(\%)\end{array}$ & $\begin{array}{c}\text { Debt to Equity } \\
\text { Ratio }(\%)\end{array}$ & $\begin{array}{c}\text { Return on } \\
\text { Investment }(\%)\end{array}$ \\
\hline 2008 & 117,40 & 7,74 & 1,58 \\
2009 & 119,57 & 6,68 & 2,94 \\
2010 & 119,28 & 4,67 & 3,68 \\
2011 & 110,29 & 5,17 & 2,98 \\
2012 & 124,44 & 5,66 & 2,71 \\
2013 & 139,10 & 5,27 & 4,21 \\
2014 & 130,18 & 5,37 & 3,12 \\
2015 & 156,04 & 2,24 & 5,24 \\
2016 & 129,06 & 2,69 & 2,01 \\
\hline
\end{tabular}

Sumber: Data sekunder diolah, Tahun 2017.

Tabel 2 menunjukkan bahwa nilai Current Ratio (CR) tertinggi dari PT. Adhi Karya (Persero) Tbk. terjadi pada tahun 2015 sebesar 156,04\%; sementara nilai terendah terjadi pada tahun 2011 sebesar 110,29\%. Namun nilai CR pada tahun 2016 mengalami penurunan dibandingkan tahun sebelumnya yaitu sebesar 26,98\%. Bila dibandingkan tahun 2008, nilai CR yang dicapai perusahaan pada tahun 2016 mengalami kenaikan sebesar 11,66\%. Hal ini menunjukkan bahwa pihak manajemen PT. Adhi Karya (Persero) Tbk. mampu mempertahankan agar nilai CR yang dicapai masih lebih besar dari 100\% yang berarti nilai aktiva lancar masih lebih besar dari nilai beban kewajiban lancar yang harus dipenuhi. Dengan kata lain, perusahaan tetap bisa mempertahankan kemampuannya untuk memenuhi semua beban kewajiban lancarnya saat jatuh tempo menggunakan aktiva lancar yang dimilikinya (Harahap, 2015; Fitriana et al., 2016). Namun demikian, perusahaan harus mewaspadai karena nilai CR pada tahun 2016 mengalami penurunan dibandingkan tahun sebelumnya yaitu sebesar 26,98\%; yang berarti terjadi penurunan kemampuan perusahaan untuk memenuhi beban kewajiban jangka pendeknya.

Nilai Debt to Equity Ratio (DER) tertinggi dari PT. Adhi Karya (Persero) Tbk. seperti ditunjukkan dalam Tabel 2 terjadi pada tahun 2008 sebesar 7,74\%; sementara nilai terendah terjadi pada tahun 2015 sebesar $2,24 \%$. Bila dibandingkan tahun 2008, nilai DER yang dicapai perusahaan pada tahun 2016 mengalami penurunan sebesar 5,05\%. Hal ini menunjukkan pihak manajemen PT. Adhi Karya (Persero) Tbk. mampu secara terus-menerus menurunkan proporsi hutang dan menaikkan kontribusi modal sendiri atau ekuitas yang digunakan untuk membiayai aset-aset perusahaan (Taufik et al., 2016; Halim, 2015). Kondisi ini perlu dipertahankan oleh pihak manajemen perusahaan, karena penurunan hutang akan mempengaruhi besaran nilai laba bersih yang bisa dbagikan sebagai dividen bagi para pemegang saham, ataupun bisa memperbesar nilai laba ditahan yang dikelola kembali ke dalam perusahaan untuk kebutuhan ekspansi misalnya, karena kewajiban perusahaan untuk membayar semua beban kewajiban jangka pendek maupun jangka panjang menjadi berkurang. Namun demikian, perusahaan tetap harus mewaspadai karena nilai DER pada tahun 2016 mengalami kenaikan dibandingkan tahun sebelumnya yaitu sebesar $0,45 \%$; yang berarti kembali terjadi peningkatan proporsi hutang yang digunakan perusahaan, dan menurunkan kontribusi ekuitas, untuk mendanai aset-aset yang dimilikinya, walau masih dalam nilai yang relatif kecil. 
Tabel 3. Hasil Regresi Linier Berganda

\begin{tabular}{llcl}
\hline \multicolumn{1}{c}{ Variabel } & Beta & t & Sig. t \\
\hline CR & 1,181 & 1,291 & 0,023 \\
DER & 1,014 & 2,014 & 0,038 \\
ROI & 2,006 & 1,912 & 0,011 \\
\hline Konstanta & 15,224 & & \\
F & 3,201 & \\
Sig. F & 0,042 & \\
R & 0,377 & \\
Adjusted R Square & 0,407 & \\
\hline
\end{tabular}

Sumber: Hasil analisis regresi (diolah), Tahun 2017.

Terakhir, Tabel 2 menunjukkan bahwa nilai Return on Investment (ROI) tertinggi dari PT. Adhi Karya (Persero) Tbk. terjadi pada tahun 2015 sebesar 5,24\%; sementara nilai terendah terjadi pada tahun 2008 sebesar $1,58 \%$. Bila dibandingkan tahun 2008, nilai CR yang dicapai perusahaan pada tahun 2016 mengalami kenaikan sebesar $0,43 \%$. Hal ini menunjukkan PT. Adhi Karya (Persero) Tbk. bisa mempertahankan efektifitas manajemennya berdasarkan hasil pengembalian dari aktivitas investasi ataupun kemampuan perusahaan dalam menghasilkan laba yang menjadi dasar kebijakan dividen perusahaan (Rusadi \& Hermanto, 2017; Fahmi, 2014; Kasmir, 2014). Dengan kata lain, perusahaan tetap bisa mempertahankan kemampuannya untuk mengelola aset-aset yang dimiliki sehingga mampu menciptakan laba bagi perusahaan. Namun demikian, perusahaan harus mewaspadai karena nilai ROI pada tahun 2016 diindikasi mengalami penurunan dibandingkan tahun sebelumnya yaitu sebesar $3,23 \%$; yang berarti terjadi penurunan kemampuan perusahaan untuk menciptakan keuntungan atau laba usaha melalui pengelolaan total aset yang diinvestasikannya.

\section{Analisis Regresi Linier Berganda}

Analisis regresi berganda dilakukan dengan software SPSS for Windows ver. 18. Hasil analisis regresi terangkum pada Tabel 3.

Berdasarkan hasil analisis nilai Beta pada Tabel 3, dapat diformulasikan model regresi linier berganda atas variabel-variabel yang dianalisis dalam penelitian ini adalah:

$$
\begin{aligned}
\mathrm{Y}= & 15,224+1,181 \mathrm{CR}+1,014 \mathrm{DER} \\
& +2,006 \mathrm{ROI}+e
\end{aligned}
$$

dimana hasil analisis tentang pengaruh dari masing-masing variabel independen terhadap variabel dependen berdasarkan model tersebut diuraikan sebagai berikut:

a. Nilai koefisien regresi untuk $\mathrm{CR}$ adalah 1,181 dengan tanda positif, yang berarti bahwa CR memiliki pengaruh yang bersifat positif atau searah terhadap return saham PT. Adhi Karya (Persero) Tbk. Dengan demikian, apabila terjadi kenaikan CR sebesar $1 \%$ maka akan menaikkan return saham perusahaan sebesar $1,181 \%$; atau sebaliknya, bahwa apabila terjadi penurunan $\mathrm{CR}$ sebesar $1 \%$ maka akan menurunkan return saham perusahaan sebesar $1,181 \%$; dengan asumsi, variabelvariabel independen lainnya tidak berubah.

b. Nilai koefisien regresi untuk DER adalah 1,014 dengan tanda positif, yang berarti bahwa DER memiliki pengaruh yang bersifat positif atau searah terhadap return saham PT. Adhi Karya (Persero) Tbk. Dengan demikian, apabila terjadi kenaikan DER sebesar $1 \%$ maka akan menaikkan return saham perusahaan sebesar 1,014\%; atau sebaliknya, bahwa apabila terjadi penurunan DER sebesar 1\% maka akan menurunkan return saham perusahaan sebesar 1,014\%; dengan asumsi, variabelvariabel independen lainnya tidak berubah. 
c. Nilai koefisien regresi untuk ROI adalah 2,006 dengan tanda positif, yang berarti bahwa ROI memiliki pengaruh yang bersifat positif atau searah terhadap return saham PT. Adhi Karya (Persero) Tbk. Dengan demikian, apabila terjadi kenaikan ROI sebesar $1 \%$ maka akan menaikkan return saham perusahaan sebesar 2,006\%; atau sebaliknya, bahwa apabila terjadi penurunan ROI sebesar $1 \%$ maka akan menurunkan return saham perusahaan sebesar 2,006\%; dengan asumsi, variabelvariabel independen lainnya tidak berubah.

d. Variabel yang memiliki pengaruh dominan terhadap return saham di dalam model penelitian ini adalah ROI sebesar 2,006; diikuti oleh CR sebesar 1,181; dan variabel yang memiliki derajat pengaruh terkecil yaitu DER sebesar 1,014.

Berikutnya, Tabel 3 menunjukkan hasil uji $t$ ( $t$-test) untuk masing variabel independen yang dianalisis, dengan uraian berikut:

a. Nilai Sig. $t$ dari variabel $C R$ sebesar 0,023 adalah lebih kecil dari $\alpha(0,05)$, yang berarti CR secara parsial berpengaruh signifikan atas return saham perusahaan. Dengan demikian, dinyatakan bahwa rasio likuiditas terbukti memiliki pengaruh parsial yang signifikan terhadap return saham PT. Adhi Karya (Persero) Tbk.

b. Nilai Sig. t dari variabel DER sebesar 0,038 adalah lebih kecil dari $\alpha(0,05)$, yang berarti DER secara parsial berpengaruh signifikan atas return saham perusahaan. Dengan demikian, dinyatakan bahwa rasio solvabilitas terbukti memiliki pengaruh parsial yang signifikan terhadap return saham PT. Adhi Karya (Persero) Tbk.

c. Nilai Sig. $t$ dari variabel ROI sebesar 0,011 adalah lebih kecil dari $\alpha(0,05)$, yang berarti ROI secara parsial berpengaruh signifikan atas return saham perusahaan. Dengan demikian, dinyatakan bahwa rasio profitabilitas terbukti memiliki pengaruh parsial yang signifikan terhadap return saham PT. Adhi Karya (Persero) Tbk.

Selanjutnya, Tabel 3 menunjukkan bahwa nilai Sig. F sebesar 0,042 adalah lebih kecil dari $\alpha(0,05)$, yang berarti bahwa ketiga variabel independen yang dianalisis dalam penelitian ini, yaitu CR, DER dan ROI, terbukti secara simultan berpengaruh signifikan terhadap return saham PT. Adhi Karya (Persero) Tbk.

Nilai R pada Tabel 3 sebesar 0,377 atau kurang dari 0,5 menyatakan bahwa variabelvariabel CR, DER dan ROI memiliki korelasi atau keeratan hubungan yang relatif lemah terhadap return saham PT. Adhi Karya (Persero) Tbk.

Nilai adjusted $R$ Square sebesar 0,407 pada Tabel 3 menyatakan bahwa variabelvariabel yang dianalisis dalam penelitian ini, yaitu CR, DER dan ROI, hanya mampu menjelaskan fluktuasi dari return saham PT. Adhi Karya (Persero) Tbk. sebesar 40,7\%; sementara sisanya sebesar 59,3\% dijelaskan melalui variabel-variabel lain yang tidak dimasukkan ke dalam model penelitian ini.

\section{Pembahasan}

Berikut akan diuraikan hasil analisis sebelumnya dengan menghubungkannya pada konsep teoritis dan hasil-hasil studi empiris sebelumnya.

\section{a. Pengaruh Rasio Likuiditas terhadap Return Saham.}

Rasio likuiditas menyatakan tingkat kemampuan perusahaan untuk memenuhi semua kewajiban lancarnya menggunakan aktiva lancar yang dimiliki pada saat jatuh tempo (Murhadi, 2013; Harahap, 2015). Pada penelitian ini, proksi dari rasio likuiditas adalah current ratio (CR). Berdasarkan hasil analisis diperoleh koefisien regresi untuk variabel CR sebesar 1,181 dengan nilai Sig. t sebesar 0,023 ( $\mathrm{p}<0,05)$. Nilai-nilai tersebut menunjukkan bahwa hipotesis pertama yang diajukan dalam penelitian ini bisa diterima atau dibuktikan kebenarannya, yaitu bahwa rasio likuiditas memiliki pengaruh yang positif dan signifikan terhadap return saham PT. Adhi Karya (Persero) Tbk.

Pembuktian hipotesis pertama dalam penelitian ini adalah memperkuat hasil studi Rusadi dan Hermanto (2017), Lestari et al. (2016), Safitri \& Yulianto (2015), Pratiwi dan Putra (2015), Wingsih (2013), serta Farkhan dan Ika (2012), menemukan bahwa rasio 
likuiditas memiliki pengaruh positif terhadap return saham. Namun, hasil penelitian ini berbeda dengan hasil studi Fitriana et al. (2009) serta Thrisye dan Simu (2013) yang menemukan rasio likuiditas tidak berpengaruh terhadap return saham.

Hasil penelitian ini memperkuat pemikiran apabila PT. Adhi Karya (Persero) Tbk. semakin mampu memenuhi semua beban kewajiban jangka pendeknya menggunakan total aktiva lancar miliknya maka semakin meminimalkan risiko gagal bayar yang dihadapi perusahaan, dan hal itu berarti meminimalkan risiko yang ditanggung para investor. Kondisi ini merupakan sinyal positif yang memperkuat keyakinan para pemegang saham terkait dengan prospek keberlanjutan perusahaan, sehingga mereka bersedia menginvestasikan dana mereka dalam jumlah lebih besar ke dalam perusahaan itu sekaligus memberikan informasi positif kepada pasar sehingga menaikkan harga saham perusahaan perusahaan. Dengan kenaikan harga saham, berarti terjadi return saham yang positif dan menmberikan capital gain bagi pemegang saham perusahaan.

\section{b. Pengaruh Rasio Solvabilitas terhadap Return Saham.}

Rasio solvabilitas menyatakan proporsi perbandingan antara total kewajiban dan total aset yang dikelola perusahaan (Halim, 2015; Harahap, 2015). Pada penelitian ini, proksi dari rasio solvabilitas adalah debt to equity ratio (DER), yang menunjukkan proporsi relatif dari utang dan ekuitas yang digunakan untuk membiayai aktiva perusahaan (Fahmi, 2014; Taufik et al., 2016).Berdasarkan hasil analisis diperoleh koefisien regresi untuk variabel DER sebesar1,014 dengan nilai Sig. t sebesar 0,038 ( $\mathrm{p}<0,05)$. Nilai-nilai tersebut menunjukkan bahwa hipotesis kedua yang diajukan dalam penelitian ini ditolak atau tidak terbukti kebenarannya, yaitu bahwa rasio solvabilitas memiliki pengaruh yang negatif terhadap return saham PT. Adhi Karya (Persero) Tbk. Hasil penelitian menemukan rasio solvabilitas berpengaruh secara positif dan signifikan terhadap return saham.

Penolakan hipotesis kedua dalam penelitian ini memperkuat hasil studi milik
Wingsih (2013), Leksono et al. (2013), Nuryanah (2013), Farhan dan Ika (2012) serta Susilowati dan Turyanto (2011), yang menemukan rasio solvabilitas berpengaruh positif terhadap return saham. Namun, hasil penelitian ini berbeda dengan hasil studi Rusadi dan Hermanto (2017), Taufik et al. (2016), Fitriana et al. (2016), Safitri dan Yulianto (2015), Thrisye dan Simu (2013), Asnita \& Astohar (2012), Ngaisah (2008) serta Papanastasopulos et al. (2010), yang mengidentifikasi bahwa rasio solvabilitas memiliki pengaruh negatif atas return saham.

Hasil penelitian ini memunculkan pemikiran bahwa sejumlah investor memberi respon positif apabila PT. Adhi Karya (Persero) Tbk. memiliki proporsi hutang lebih besar dibandingkan ekuitas di dalam struktur modalnya. Argumen yang muncul adalah adanya pandangan investor yang menilai apabila perusahaan memperbesar kontribusi hutang dalam struktur modalnya bisa merupakan sinyal positif bahwa perusahaan mengalami pertumbuhan dan membutuhkan tambahan dana operasional yang tidak bisa dipenuhi hanya melalui modal sendiri perusahaan. Dengan demikian, proporsi hutang yang lebih besar daripada ekuitas menyatakan bahwa prospek perusahaan tumbuh berkembang di masa datang semakin besar, sehingga menciptakan sentimen positif dari pasar atas perusahaan, menarik lebih banyak investor yang berinvestasi pada perusahaan itu, dan selanjutnya meningkatkan return saham perusahaan. Namun demikian, pihak manajemen perusahaan perlu berhatihati karena semain besar nilai hutang yang dimiliki akan memperbesar risiko gagal bayar ataupun kebangkrutan bagi perusahaan (Susilowati \& Turyanto, 2011; Natarsyah, 2000).

\section{c. Pengaruh Rasio Profitabilitas terhadap Return Saham,}

Rasio profitabilitas menyatakan derajat kemampuan perusahaan dalam menghasilkan laba melalui pengelolaan asset-aset yang diinvestasikan (Copeland et al., 2013; Kasmir, 2014). Pada penelitian ini, proksi dari rasio profitabilitas adalah return on investment (ROI), yang menunjukkan besaran 
perbandingan antara laba operasional yang berhasil diraih perusahaan dengan semua aset yang dimilikinya (Halim, 2015; Nuryana, 2013). Berdasarkan hasil analisis diperoleh koefisien regresi untuk variabel ROI sebesar 2,006 dengan nilai Sig. $t$ sebesar 0,011 ( $<$ < 0,05). Nilai-nilai tersebut menunjukkan hipotesis ketiga yang diajukan dalam penelitian ini diterima atau dapat dibuktikan kebenarannya, yaitu bahwa rasio profitabilitas berpengaruh positif dan signifikan terhadap return saham PT. Adhi Karya (Persero) Tbk.

Pembuktian hipotesis ketiga dalam penelitian ini memperkuat hasil studi milik Rusadi dan Hermanto (2017), Leksono et al. (2016), Nuryana (2013), Thrisye dan Simu (2013), Farkhan dan Ika (2012), Fitriana et al. (2009), serta Susilowati dan Turyanto (2011), yang menemukan bahwa rasio profitabilitas berpengaruh positif terhadap return saham. Namun, hasil penelitian ini berbeda dengan hasil studi Lestari et al. (2016), Safitri dan Yulianto (2015), Arista dan Astohar (2012), serta Wingsih (2013), yang mengidentifikasi bahwa rasio profitabilitas berpengaruh negatif terhadap return saham.

Hasil penelitian ini menyatakan bahwa bila PT. Adhi Karya (Persero) Tbk. mampu menunjukkan kinerjanya berupa pengelolaan total aktivanya secara baik sehingga menghasilkan laba yang tinggi maka akan memperoleh respon pasar yang positif. Bila perusahaan mampu menciptakan nilai rasio profitabilitas yang tinggi, maka akan memberi sinyal kepada para pemegang sahamnya bahwa perusahaan yang bersangkutan mampu mengelola asset-aset yang dimilikinya dengan baik dan bisa menghasilkan laba perusahaan yang tinggi, dan dalam kelanjutannya akan meningkatkan kemakmuran para pemegang sahamnya. Kondisi itu semakin mendorong minat para investor untuk menginvestasikan lebih banyak dananya ke dalam perusahaan melalui instrumen saham, dan selanjutnya menghasilkan return saham yang positif atau capital gain bagi pemilik perusahaan.

\section{KESIMPULAN}

Berdasarkan hasil-hasil penelitian dan pembahasan yang telah dikemukakan, dapat disimpulkan ketiga variabel independen yang dianalisis dalam penelitian ini, yaitu rasio likuiditas, rasio solvabilitas, dan rasio profitabilitas, memiliki pengaruh yang positif dan signifikan baik secara parsial maupun simultan terhadap return saham. Hasil analisis ini membuktikan kebenaran dari hipotesis pertama dan ketiga, tetapi menolak hipotesis kedua. Derajat korelasi maupun kemampuan menjelaskan dari ketiga variabel independen dalam model penelitian ini atas fluktuasi yang terjadi atas return saham PT. Adhi Karya (Persero) Tbk. juga relatif rendah.

Berdasarkan beberapa kesimpulan itu, maka direkomendasikan pihak manajemenPT. Adhi Karya (Persero) Tbk. agar selalu memperhatikan aspek-aspek rasio keuangan karena terbukti baik secara parsial maupun simultan mempengaruhi return saham. Besaran return saham yang positif bisa menjadi sinyal positif berkaitan kinerja perusahaan di mata para investor, karena menunjukkan mereka akan memperoleh capital gain melalui kepemilikan saham mereka atas PT. Adhi Karya (Persero) Tbk. kondisi itu akan menarik mereka untuk berinvestasi lebih banyak pada saham perusahaan bersangkutan, dan selanjutnya akan menaikkan nilai perusahaan di pasar.

Berdasarkan perbandingan koefisien regresi diidentifikasi bahwa aspek rasio profitabilitas memiliki pengaruh dominan terhadap return saham PT. Adhi Karya (Persero) Tbk. Hal ini mengisyaratkan bahwa manajemen perusahaan harus mampu mengelola total aset yang dimiliki dengan baik sehingga mampu menghasilkan tingkat laba bersih yang tinggi, sehingga bisa menciptakan nilai ROI yang terus meningkat. Peningkatan ROI merupakan sinyal positif dan bisa mempengaruhi minat investor berinvestasi pada saham perusahaan, sehingga dapat menaikkan nilai pasar dan selanjutnya menghasilkan return saham yang positif.

Walau demikian, derajat korelasi maupun determinasi yang rendah dari ketiga rasio keuangan yang dianalisis dalam penelitian ini menyatakan bahwa pihak manajemen juga seharusnya memperhatikan 
aspek-aspek fundamental lain yang dinilai mempengaruhi return saham perusahaannya.

Keterbatasan lain dari perusahaan adalah hasil penelitian ini terbatasi pada analisis saham PT. Adhi Karya (Persero) Tbk. saja. Dengan demikian, disarankan agar peneliti selanjutnya untuk mengkomparasikan pada perusahaan-perusahaan terbuka lainnya dalam sektor industri yang sama atau berbeda, sehingga bisa diperoleh pemahaman yang komprehensif mengenai hubungan antara rasio keuangan dan return saham.

\section{DAFTAR PUSTAKA}

Arista, D. dan Astohar. 2012. Analisis FaktorFaktor yang Mempengaruhi Return Saham (Kasus pada Perusahaan Manufaktur yang Go Public di BEI Periode tahun 2005 - 2009). Jurnal Ilmu Manajemen dan Akuntansi Terapan. Vol. 3, No. 1, hal. 1-15.

Brigham, E.F. dan Houston, J.F. 2011. DasarDasar Manajemen.Keuangan. Edisi 10. Jakarta: Salemba Empat.

Copeland, T.E., Weston, H.F. dan Shastri, K. 2013. Financial Theory and Corporate Policy. Pearson New International Edition. Fourth Edition. London: Pearson Education Limited.

Damodaran, A. 2014. Applied Corporate Finance. Fourth Edition. New York, United States: John Wiley \& Sons Inc.

Fahmi, I. 2014. Analisis Laporan Keuangan. Bandung: Alfabeta.

Farkhan dan Ika. 2012. Pengaruh Rasio Keuangan terhadap Return Saham Perusahaan Manufaktur di Bursa Efek Indonesia (Studi Kasus pada Perusahaan Manufaktur Sektor Food and Beverage). Value Added. Vol. 9, No. 1, hal. 1-18.

Fitriana, D., Andini, R. dan Oemar, A. 2016. Pengaruh Likuiditas, Solvabilitas, Profitabilitas, Aktivitas dan Kebijakan Dividen terhadap Return Saham Perusahaan Pertambangan yang Terdaftar pada BEI Periode 2007-
2013. Journal of Accounting. Vol. 2, No. 2, Maret.

Fuad, M., Nurbaya, S. dan Amirullah. 2017. Pengantar Bisnis. Yogyakarta: Indomedia Pustaka.

Gumanti, T.A. 2017. Keuangan Korporat: Tinjauan Teori dan Bukti Empiris. Jakarta: Mitra Wacana Media.

Halim, A. 2015. Manajemen Keuangan Bisnis: Konsep dan Aplikasinya. Jakarta: Mitra Wacana Media.

Harahap, S.S. 2015. Analisis Kritis atas Laporan Keuangan. Jakarta: Rajawali.

Harjito, A. dan Martono. 2011. Manajemen Keuangan. Edisi Kedua. Yogyakarta: Ekonisia.

Kasmir.2014. Analisis Laporan Keuangan. Edisi Satu. Cetakan Ketujuh. Jakarta: PT. RajaGrafindo Persada.

Leksono, A., Syafi'i, dan Pudjowati, J. 2015. Pengaruh Rasio Likuiditas, Profitabilitas, dan Solvabilitas terhadap Harga Saham Perusahaan Perbankan di BEI Periode 2009-2013. EQUITY. Vol 1, No. 2, hal. 12-22.

Lestari, K., Andini, R. dan Oemar, A. 2016. Analisis Likuiditas, Leverage, Profitabilitas, Aktivitas, Ukuran Perusahaan dan Penilaian Pasar terhadap Return Saham (Pada Perusahaan Real Estate dan Property di BEI).Journal of Accounting.Vol. 2, No. 2, hal.1-19.

Murhadi, W.R. 2013.Analisis Laporan Keuangan: Proyeksi dan Valuasi Saham. Jakarta: Salemba Empat.

Natarsyah, S. 2000. Analisis Pengaruh Faktor Fundamental dan Risiko Sistematik terhadap Harga Saham (Kasus Industri Barang Konsumsi yang Go-Public Di Pasar Modal Indonesia). Jurnal Ekonomi dan Bisnis Indonesia. Vol. 15, No. 3, hal. 294-312.

Ngaisah. 2008. Pengaruh Rasio Profitabilitas dan Leverage terhadap Return Saham pada Perusahaan yang Terdaftar di Jakarta Islamic Index Tahun 2004- 
2006. Jurnal Ilmu Manajemen. Vol. 2, No. 1, hal. 1-15.

Nuryana, I. 2013. Pengaruh Rasio Keuangan terhadap Return Saham Perusahaan LQ 45 di Bursa Efek Jakarta. Jurnal Akuntansi Aktual. Vol. 2, No. 2, hal. 57-66.

Papanastasopoulos, G., Thomakos, D. dan Wang, T. 2010. The Implication of Retained and Distributed Earnings for Future Profitability and Stock Returns. Review of Accounting and Finance. Vol. 9, No. 4, hal. 395-423.

Pratiwi, T.W. dan Putra, I.W. 2015. Pengaruh Rasio Keuangan, Ukuran Perusahaan, Arus Kas Aktivitas Operasi Pada Return Saham. E-Jurnal Akuntansi. Vol. 11, No. 2, hal. 531-546.

Rusadi, P.L. dan Hermanto, S.B. 2017. Pengaruh Profitabilitas, Likuiditas, Leverage, Aktivitas dan Nilai Pasar terhadap Return Saham. Jurnal Ilmu dan Riset Akuntansi. Vol. 6, No. 10, hal.1-22.

Safitri, R. D. dan Yulianto, A. 2015. Pengaruh Kinerja Keuangan Perusahaan terhadap Return Total Saham pada Perusahaan Manufaktur yang Terdaftar di Bursa Efek Indonesia. Management Analysis Journal. Vol. 4, No. 1, hal. 22-29.

Sartono, R.A. 2014. Manajemen Keuangan - Teori dan Aplikasi. Edisi 4. Yogyakarta: BPFE.
Subramanyam, K.R. dan Wild, J. 2013. Financial Statement Analysis. New York: McGraw-Hill Higher Education

Susilowati, Y. dan Turyanto, T. 2011. Reaksi Signal Rasio Profitabilitas dan Rasio Solvabilitas terhadap Return Saham Perusahaan. Dinamika Keuangan dan Perbankan. Vol. 3, No. 1, hal. 17-37.

Tandelilin, E. 2010. Portofolio dan Investasi: Teori dan Aplikasi. Yogyakarta: Kanisius.

Taufik, F.A., Raharjo, K. dan Abrar. 2016. Pengaruh Return on Asset, Debt to Equity Ratio, Earning per Share dan Price to Book Value terhadap Return Saham pada Perusahaan Real Estate and Property yang Terdaftar di BEI. Journal of Accounting.Vol. 2, No. 2, Maret.

Thrisye, R.Y. dan Simu, N. 2013. Analisis Pengaruh Rasio Keuangan terhadap Return Saham BUMN Sektor Pertambangan Periode 2007-2010. JIAB (Jurnal Ilmiah Akuntansi dan Bisnis).Vol. 8, No. 2, hal. 75-81.

Wingsih, Y. 2013. Analisis Pengaruh Likuiditas, Profitabilitas, dan Solvabilitas terhadap Return Saham pada Perusahaan Pertambangan yang Terdaftar di Bursa Efek Jakarta pada Tahun 2008 sampai 2012. Jurnal Manajemen. Vol. 1, No. 2, hal. 1-23. www.idx.co.id 